\title{
THE SOCIOLINGUISTICS OF HONORIFICS IN ENGLISH COURTROOM INTERACTION
}

Prof. Dr. Salih Mahdi Adai Al-Mamoory (Ph.D.) ${ }^{1}$

\section{Asst. lect. Hasan Imad Kadhim²}

${ }^{1}$ English Department, College of Education for Human Sciences, Babylon, University, Iraq.

Email: salih_mehdi71@yahoo.com

2 Department of English, Al-Mustaqbal University College, Hilla, Babil, Iraq

Email: hasan.imad@mustaqbal-college.edu.iq

HNSJ, 2022, 3(2); https://doi.org/10.53796/hnsj3245

\section{Published at 01/02/2022}

Accepted at 14/12/2021

\begin{abstract}
Honorifics are derived from outputs of politeness strategies where these directly or indirectly convey a status deferential between speaker and addressee or referent .When we investigate the conversations of English language regardless the country of that language we notice some use honorific expression and some are less using or even not using them and these honorifics are used within certain style. This paper tries to answer the question why they are used in some occasions and why not used in some other occasions. The research paper aims at analyzing the honorifics from Sociolinguistics point of view which are used in English, and finding the functions and the uses of these honorifics, and how the style changes from one person to another. The samples of honorifics are taken from Courtroom interaction. After analyzing these samples, we find out two types of honorifics (phrasal, lexical) that are used in courtroom interaction and the style is formal. The paper concludes that most honorifics that are used by members of English Judges and lawyers are routine formulas and they follow formal style. The use of honorifics is not based on the relationship between the speaker and the addressee; it is based on the social rank of the addressee or the situation.
\end{abstract}




\subsection{Introduction}

\section{Sociolinguistics}

The study of the linguistic features which have social relevance to participants in a community is known as Sociolinguistics. Sociolinguistics deals with the relationships between language and the context in which that language is used. Language is used to ask for and to give people information. Language is also used in order to express admiration, respect and even indignation. In other words, sociolinguistics generally investigates the effect of the aspects of society, including the cultural norms and the context in which the language is used in a society (Eble, 1998:42).

Sociolinguistics studies the relationship between languages and societies. Sociolinguists are interested in explaining why speakers use language differently in different social contexts, and they are concerned with the identifications of the social functions of the language and the ways in which it is used in order to convey social meanings. This means that the same message can be expressed differently in different societies. It studies how language varieties vary between groups that are determined by certain social classes (Coulmas, 1998: 4).

\section{Stylistic Variation}

In sociolinguistics, the concept of stylistic variety is always present. Rickford and Eckert (2001: 88) suggest that there are three reasons to look at style when investigating variance. Individuals and groups, for starters, typically have their own stylistic repertoire. The manner, in which they are documented, for example, may have an impact on sociolinguistic analysis. Second, stylistic variance in speech can provide signs of linguistic change in the making. Third, analyzing styles can help us understand individuals' internationalization of the social meaning of variation.

From an anthropological aspect, Irvine (2001: 58) views style as the social semiosis of distinctiveness, Irvine focuses on the community dynamics that produce uniqueness. According to Irvine, ideology plays a significant effect in the speakers' style selection. Speakers' awareness of their own social positions, the degrees to which they gain access and the social space by which they are bounded all influence how they act and speak ideologically.

According to Eckert (2002:1) Speech, textbooks, religion lectures, meetings, and department mail all adopt an official or formal style of language. As a standard, patterns and formal register are set in stone. The official register is the same as the standard language variation that is exclusively used in formal settings and not in informal ones. As a result, this style does not apply to interactions between close friends or family members. However, in a discussion in a lecture class or with the dean in his office.

According to Simpson (2004:22), in language, style is a choice that is everyday shaped and defined by actions, events, thoughts and perceptions, it is an important 
function of the language system that is able to account for these various going on in the world.

Llamas (2007:95) define language style as a dimension of language in which individual speakers have a choice. People do not speak in consistently the same way. But in fact people always shifting the way they speak constantly as they move from one situation in to another. Style is referred to as the linguistic idiosyncrasy of an individual. It is personal. Style in the social roles includes an expected behavior linked with a particular status. It is much more flexible than status and also varies according to the speech situation.

According to Hornberger (2010:177) People typically speak in a variety of ways, which has piqued the interest of sociolinguists in recent decades. Oriented sociolinguists to try to map with what frequency speakers traditionally altered styles based on social settings, and as a result, shown how social hierarchies are inscribed on routine speech patterns. As a result, speech and style are the byproducts, or sediments, of the previous engagement. In turn, the engagement might be described as style or speaking in motion.

\section{Types of Style}

Joos (1967:153-156) states that Frozen, Formal, Casual, Consultative, and Intimate style are among the five types of styles illustrated. The frozen style is one that is meant to be remembered and utilized in extremely formal settings such as palace and church rituals. It's also mentioned in a sermon that most people don't know each other. It signifies that the manner in which speech is used is determined by the form in which it is used. In this circumstance, neither the speaker nor the listener is allowed to pose a question. Frozen style is a formal speech style that is most often utilized in formal situations. It's dubbed "Frozen" because the pattern is set in stone and cannot be altered. The sentence in the frozen style is longer than the others. The listener must take seriously the speech of this style. This style is usually used in literary book, presidental speech, wedding ceremony, etc. For the patterns, it seems like a standard language that only used in formal situation. So, for conversation between friends, it does not use this kind of language variety. The speaker must plan ahead, framing whole sentences before they are delivered. It is also used in speaking to a single hearer.

The formal or deliberative style of language is defined as the type of language used in situations where the speakers are highly attentive about their pronunciation, word choice, and sentence construction. It's typically utilized in serious or critical contexts, such as academic and technical reports, classrooms, formal speeches, and sermons. A single topic, a sentence structure that shows less closeness between the speaker and the hearer, and the use of conventional forms are all elements of formal style. The formal style is employed in formal situations where communication is oneway, i.e. there are no interruptions. Its objective is to inform someone about something 
essential, thus the speaker may need to prepare beforehand. This pronunciation is artificially explicit.

Consultative style is that shown in our norm for coming to term with strangers who speak our language but whose personal stock of information may be different. It is the style that is used in semi-formal situation. It happens in twoways participation that means it must be a pair conversation. The consultative style can be found in conversation between teacher-student, doctor-patient and etc. This style can be used in formal situation and informal situation. Another characteristic of this style is in the structure of the sentences. It has subject and predicate in every utterance, but some word of vocabulary are non-standard ones. This is because actually consultative style is produced in semi-formal situation.

Casual style is a style that is used for the conversation in informal situation that is appropriate to conversation with friends, co-worker, and each other such as outside the classroom when the student have a chat. The situation is informal. It can be found in chat out of class room where language does not bound with grammatical rules. The vocabulary that is used are influenced the dialect. Casual style is characterized by use of slang. Slang is non-standard form of word which is known and used by a certain group.. This is a prime indication of in-group relationship. It is used only with insiders, and it an assumed to know only by members of the group. For example: to teenagers or to some clique among adolescents.

Intimate language style is a completely private language developed within families, lovers, and the close friends. Normally the intimate group is pair the intimate labels like dear, darling, honey, mom, dad or other nicknames might be used in this situation. Intimate language style excludes public information Of course, it is not public assumption, it means that intimate has private vocabularies with the addressee. It manifests extremely structural simplicity. Intimate language style is usually used by participants who have very close relationship, like between family members, between close friends. This language can be identified by the use of incomplete language, short words, and usually with unclear articulation. This because between participants already understood each other. The reasons for using intimate language style are to express feeling between the speakers, to express intimate phenomena. By using intimate language style, the most informal atmosphere can be produced, and automatically skip the distance and create comfortable communication.

Business style or consultative style is one variation of the language that speakers commonly use in regular talks such as that in schools, meetings or exchange oriented to results or production. it can be said that the great diversity of this style is the most operational. This form of business style is mixing between formal and informal or casual style.

Familiarity style or intimate style is one variety of language used commonly by the speakers who are already in familiar relationship. This type of style is characterized 
by the use of shortened, uncompleted language and with often not clear articulation. This occurs because there are already mutual understanding and the same knowledge between the participants.

Chaer and Agustina (2010:70-71) regard Frozen style as the most formal language variation and it is used in solemn situations, official ceremonies, for example, sermons in mosques, the books of law, notary, and decision letters. It is also called the frozen register since the pattern and its rules are firmly set in and should not be modified. In written form, frozen register is found in historical documents, such as papers, the basic law, notary, purchase agreement. The ordered sentences in the frozen variety are usually rigid, long, and complete words. Thus speakers and listeners of frozen register require seriousness and attention.

\section{Deixis}

Deixis, in general, is a term derived from the Greek word "pointing, indicating, and showing". "Deixis is generally concerned with the relationship between the structure of a language and the context in which the language is used" (Huang, 2014)

\subsubsection{Types of deixis}

There are five types of deixis

- Person deixis (I, We)

- Place, space deixis( here, there)

-Time deixis (just now, then, tomorrow morning)

- Discourse deixis (that's the silliest joke I've ever heared) "that's" is a discourse deictic expression pointing back to the previous chunk of talk.

\subsubsection{Social deixis}

Social deixis deals with the social status and the social relationship between the participants of a communicative act. The social relationship between the participants determines the choice of honorific, polite or insulting speech level. (Huang, 2014)

"The information encoded in social deixis may include social class, kin-relationship, age, sex, and profession" (Huang, 2014)

Social deixis are of two types:

\subsubsection{Absolute and Relational}

Absolute social deixis are forms that are used to address an authorized speakers or recipients.

Relational social deixis can be illustrated by the use of honorifics. 


\subsubsection{Honorifics}

\section{The Concept of Honorifics:}

Honorifics are derived from outputs of politeness strategies where these directly or indirectly convey a status deferential between speaker and addressee or referent, where they indirectly convey such a status deferential, as in French Tu / Vous pronouns do via the general strategy of pluralizing in order to impersonalize (Brown and Levinson 1978: 183).

Honorifics have been defined as "politeness formulas in a particular language which may be specific affixes, words, or sentence structure" (Richard et al., 1985: 131). Languages which have a complex system of honorifics are, for instance, Japanese, Mudurese (a language of Eastern Java), Hindi, and Arabic; English, on the other hand, has no complex system of honorifics, but there are few cases of compound honorifics; e.g. professor doctor, dear, sir, etc. (ibid: 131).

\section{Categories of Honorifics:}

Levinson (1983: 90 -91) points out that honorifics can be divided into two main types. The first type is called „relational ${ }^{\text {le }}$ which is more important than the second one and mainly concerned with the socially deictic information in languages of the world. Within this relational system of honorifics, three subcategories are distinguished; they are addressee honorifics, referent honorifics and by-stander honorifics. The second type of honorifics in Levinson "s typology is called ,absolutee honorifics which express the relationship between the speaker and the setting through formality levels. Absolute honorifics are categorized into ,authorized speakers" and ,authorized recipients according to the perspectives of the speakers and recipients.

\section{- Speaker and referent (referent honorifics)}

Referent honorifics are forms that are used to show respect to the person referred to (the referent)

\section{- Speaker and addressee (addressee honorifics)}

Addressee honorifics, as Comrie, (1976) argues, refer to the relationship between the speaker and the hearer.

Brown and Levinson (1987: 276) point out those addressee honorifics are direct encodings of the speaker-addressee relationship, independent of the referential content of the utterance.

Addressee honorifics are forms of address that are used to show respect "professor "to the addressee, for example 


\section{- Speaker and bystander (bystander honorifics)}

Bystander honorifics that are used to show deference to a bystander, including participant in the role of audience and non-participant over hearers (Levinson, 1983)

-Speaker- setting honorifics

They determine the forms which are used in formal and informal occasions. (ibid)

\section{Absolute Honorifics:}

These sets of honorifics refer to the relationship between speaker (and perhaps other participants) and setting (or social activity). What is important here is the distinction between formality and informality which colours the relationship between the participants ${ }^{\text {ee }}$ roles and situations. As a matter of fact, there are certain forms which are particularly reserved for certain speakers and other forms which are reserved for certain recipients. The first sets of forms are used by ,authorized speakers ${ }^{\text {ee }}$, for example the form of the first person pronoun is specifically reserved for the use of the Japanese Emperor. The second set of forms is particularly.

\subsubsection{Formal Title}

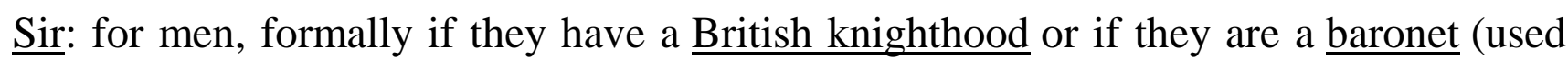
with first name or full name, never surname alone) or generally (used on its own) as a term of general respect or flattery, when it is equivalent in meaning to "Madam" for women (see below). Also traditionally used to address male teachers in British schools. Gentleman: Originally a social rank, standing below an esquire and above a yeoman. The term can now refer to any man of good, courteous conduct. It is only generally used as an honorific form of address in the plural ("gentlemen" if referring to a group of men, or as part of "ladies and gentlemen" if referring to a mixed group), with "sir" (or "ladies and sir") being used for the singular.

- Sire: a term of address for a male monarch, previously could be used for a person in a position of authority in general or a lord.

- Mistress is an archaic form of address for a woman, equivalent to Mrs. Used on its own, it was used to address the female head of a household. The titles $\underline{\mathrm{Mrs}}, \underline{\text { Miss }}$ and $\underline{\mathrm{Ms}}$ are abbreviations derived from Mistress.

- Madam or Ma'am is a term of general respect or flattery. Originally used only to a woman of rank or authority. May also refer to a female pimp. Equivalent to "Sir"

- All of "Sir", "Madam", and "Ma'am" are commonly used by workers performing a service for the beneficiary of the service, e.g. "May I take your coat, Ma'am?"

- "Madam" is used with the name of an office to address a woman who is the office-holder, e.g. "Madam President". 
- Lord: for male barons, viscounts, earls, and marquises, as well as some of their children. In some countries judges, especially those of higher rank are referred to as lords, ladies or lordship/ladyship. (Style: Lordship or My Lord).

- Lady: for female peers with the rank of baroness, viscounts, countess, and marchioness, or the wives of men who hold the equivalent titles. By courtesy the title is often also used for wives of Knights and Baronets. (Style: Your Ladyship or My Lady). As a plural, it may be used as an honorific for women generally ("ladies" if referring to a group of women, or as part of "ladies and gentlemen" if referring to a mixed group); "madam" (or "madam and gentlemen") is used in the singular.

- Excellency, also Excellence, a title of honor given to certain high officials, as governors, ambassadors, royalty, nobility, and Roman Catholic bishops and archbishops, (preceded by his, your, etc.).

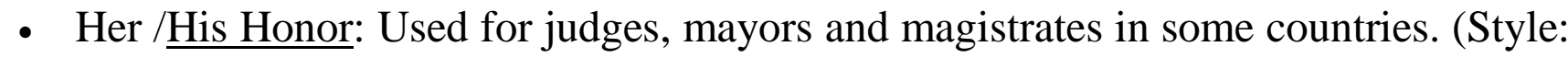
Your Honor)

- The Honourable or The Honorable (abbreviated to The Hon., Hon. or formerly The Hon'ble, used for certain officials, members of congress, parliament, presidents, and judges (Style: My Lord/Lady or Your Lordship/Your Ladyship, Mr./Madam Ambassador, Your Honor)

- The Most Honourable: for marquesses and marchionesses (and, as a group the Most Honourable Order of the Bath and Her Majesty's Most Honourable Privy Council).

\subsubsection{Academic and professional titles}

- Dr: (abbreviation for Doctor) for the holder of a doctoral degree (e.g. $\underline{\mathrm{PhD}}, \underline{\mathrm{DPhil}}, \underline{\mathrm{MD}}$, or $\underline{\mathrm{DO}}$ in many countries) and for medical practitioners, dentists and veterinary surgeons (including as a courtesy title in countries where these professionals do not normally hold doctoral degrees), although in some countries it is normal to address surgeons as "Mr", "Ms", etc. The informal abbreviation "doc" is sometimes used. UK citizens who hold doctoral degrees or are registered medical practitioners may have the title "Doctor" recorded in their passports.

- Professor: (informally abbreviated to "prof")) for a person who holds the academic rank of professor in a university or other institution. In the UK this is a senior academic position and the title is always used in preference to "Dr", while in the US it refers to tenured or tenure-track academic staff and the title "Dr" is often preferred. Professors may have their title recorded in UK passports.

- Principal, President, Master, Warden, Dean, Regent, Rector, Provost, Director, or Chief Executive: as appropriate for heads of colleges at the universities of 
Cambridge, Durham, London and Oxford, heads of the constituent universities of the National University of Ireland, and the head of Trinity College Dublin.

- Note titles sometimes double up, e.g. "Vice-Chancellor and Warden" at Durham University or "Provost and President" at University College London

\subsection{Analysis}

\section{AN INTERACTION BETWEEN LAWYERS AND A JUDGE}

Lawyer 1: We have a matter lined up for the dowry case, your honour.

Judge: Yes go ahead. Present your case.

Lawyer 1: My client has been accused of demanding dowry. But he has been wrongly accused. He is innocent.

Judge: Well that I will decide that. To arrive at an impartial judgment, I need to hear facts of the case from both the parties.

Lawyer 1: Sure your honour. But before we proceed I would like to request you to move the date for the hearing to next week as I have another case at the Supreme Court.

Judge: For that you need to submit a written request to me and to the opponent's lawyer.

Lawyer 1: Sure my lord. I have already dispatched one copy to the concerned entity.

Judge: After receiving the approval from the plaintiff's lawyer I will be decide upon the next date of hearing.

Lawyer 1: Thank you my lord for your consideration.

Judge: Does the plaintiff's lawyer have something to say on the behalf of her client?

Lawyer 2: Yes my lord. My client was harassed for the dowry by her in-laws since the very next day of her marriage. She was also physically assaulted by her husband and his family.

Lawyer 1: I object my lord. They just had a verbal fight on a trivial domestic issue.

Lawyer 2: They just had a petty argument and she got seriously injured. Isn't that shockingly astonishing?

Lawyer 1: No! That's absolutely not true.

Lawyer 2: Oh please! Your client is an unruly man and he belongs in prison.

Judge: Order! Order! Both the lawyers settle down and maintain the decorum of court. I would hear arguments from both the sides in next hearing. By that time court is adjourned. (Web source 2)

In this conversation in the courtroom among the judge and the two lawyers. We have 
noticed the use of "Honorifics" honorific expression used by the two lawyers addressing the judge politely. To indicate great respect towards the judge and how the judge higher than them in social rank.

The expressions are:

1 - Your honour

2- My lord

\section{Discussion of the Analysis}

In the above conversation we notice that honorific expressions are clearly manifested and realized by courtroom interaction among judges, lawyers, and convicts. Honorific expressions are used in formal occasions and addressed to high ranked people, while they are not or less used in informal occasions or when addressed to lower-class people.

\section{Conclusions}

This research paper has come up with the following conclusions:

-Most honorifics that are used by members of English Judges and lawyers are routine formulas and they follow formal style.

-The use of honorifics is not based on the relationship between the speaker and the addressee; it is based on the social rank of the addressee or the situation.

-There are different implied meaning of honorifics depending on the speaker and situation.

- Honorific expressions are used in formal occasions and addressed to high ranked people, while they are not or less used in informal occasions or when addressed to lower-class people. 


\section{Bibliography}

Comrie, B. (1976): "Linguistic Politeness Axes: Speaker-Addressee, Speaker-Referent, Speaker - By - Stander". In: Pragmatic Microfiche, 1.7: A3. University of Cambridge, Dept. of Linguistics.

Coulmas, Florian. (1998). The Handbook of Sociolinguistics. Oxford: Blackwell Publishers.

Brown, P. and Levinson, S. (1978): “Universals In Language Usage”. In: E.N. Goody (ed.), Questions and

Fillmore, C. J. (1971). Lectures on deixis. Berkeley: University of California.

Forrester, M. A. (1996). Psychology of language. London: SAGE publication Ltd.

Hornberger H. Nancy.( 2010). Sociolinguistics and Language

Education. USA: Short Run Press.Ltd.

Joos, M. (1967). The styles of The Five clocks. Massachusetts: Winthrop Publishers

Huang, Y. (2014). Pragmatics. United Kingdom: Oxford University Press.

Levinson, S. C. (1983). Pragmatics. United Kingdom: Cambridge University press.

Richard, J. Platt, J. and Weber. H. (1985): Longman Dictionary of Applied Linguistics, London: Longman Group Ltd.

Eble, C. (1998). Slang and Sociability. London and Chapel Hill. University of North Carolina Press

Simpson Paul.( 2004). Stylistics. London \& New York: The Routledge.

Eckert Penelope \& Rickford R John.( 2001). Style and Sociolinguistics Variation. New York:Cambridge University Press.

Irvine, Judith . (2001). Style as distinctiveness: The culture and Ideology of Linguistic Differentiation. In Style and sociolinguistic variation, ed. Penelope Eckert and John R. Rickford, 21-43. Cambridge: Cambridge University Press.

Watt, Dominic, Carmen Llamas, \& Daniel Ezra Johnson.( 2010).

Levels of Linguistic Accommodation across National Borders. Journal of English Linguistics. SAGE Publication.

Yule, G. (1996). Pragmatics. New York: Oxford University Press. https://goodreadingfor.blogspot.com/2013/10/a-dialogue-between-teacher-andstudent 12.html $12^{\text {th }}$ November 2018 at 4:17 P.M (web source ) 